\title{
From Positivism to Post-Positivism: Progress or Digression?
}

\begin{abstract}
During the first half of the $20^{\text {th }}$ century, approaches developed across the social sciences that were strongly influenced by positivist ideas. Indeed, it could be said that the very notion of a social science was positivist in origin. Moreover, even after positivism's influence had waned in many fields, in the second half of that century, it continued to exist at the very least as a ghostly presence, serving as a recurrent target for attack in methodological disputes. I begin by briefly outlining the history of positivist ideas and the various forms they took, along with their implications for the practice of social science. Then I consider two distinct varieties of 'post-positivism'; one revisionist, the other much more radical. I conclude by considering in what respects these moves beyond positivism represent progress, and whether anything can still be learned from it today.
\end{abstract}

Keywords: positivism and social science, post-positivism, Comte, political arithmetic, constructionism

As used by social scientists today, the word 'positivism' has little clear cognitive meaning. ${ }^{1}$ To a large extent, its sense has become primarily emotive, simply conveying a strongly negative evaluation. Thus, few people would now selfidentify as positivists. However, this was not always the case, and there is much to be learned by looking back at what the word originally meant, and at some of the directions in which efforts to go beyond positivism, in other words to be post-positivist, have taken. ${ }^{2}$ Of course, this issue cannot be examined in any depth within the space of a short article, but I hope that these brief reflections may be useful in countering the distorted views of positivism which, it seems to me, now prevail.

This has been true for some time, see Cohen, 1980. As we shall see, there is also a tendency to conflate its meaning with that of another polysemantic word, 'realism'.

2 I am using the term 'post-positivism' here to refer to what came after, and (to one degree or another) in reaction against 'positivism' in the field of social science methodology. As I indicate later, this term is often used in a narrower sense to refer to efforts to reform positivism. 


\section{A brief history of positivism}

The term 'positivism' appears to have been first used in the 1820s, in French, most influentially by Auguste Comte as a label for his 'positive philosophy' (Pickering, 1993a: pp. 580-581); though many of the ideas to which it referred have a longer history. ${ }^{3}$ Comte's philosophy was intended to exemplify and promote the scientific mode of thought which he believed was becoming dominant, superseding the theological and metaphysical forms that had prevailed in earlier periods of European history. Comte's ideas had great influence on social science in the nineteenth and into the twentieth century, directly as well as indirectly through the work of others, such as Mill and Durkheim.

Another source of what later came to be referred to as positivism in social science was the development of 'political arithmetic'. One version of this was the production and analysis of statistical information about national societies, including about specific social problems such as notably poverty (see Halfpenny, 1982, ch. 2; Abrams, 1972; Oberschall, 1972). Another, concerned for example with political representation, was developed by Condorcet and others - Madame de Staël believed that this would "yield results so positive that one might succeed in reducing all the problems of the moral sciences to mathematical series, to deductions and proofs" (quoted in Manuel, 1956, p. 60; see Baker, 1975). In the $19^{\text {th }}$ century the production of social statistics expanded considerably, aimed at documenting social facts of use in national policymaking and in social reform. Furthermore, towards the end of that century, new statistical techniques were developed for analysing such data (Porter, 1986).

Both these influences on what later came to be called positivism in social science drew on the spirit of $18^{\text {th }}$-century Enlightenment ideas. At the same time, Comte deviated from that spirit in some important respects: like other writers in the post-Jacobin and Napoleonic period, notably the Ideologues, he sought a means of 'stabilising' the French Revolution, building on it but at the same time restoring social order (Staum, 1996; Pickering, 1993b). His outlook also differed significantly from much Enlightenment thought in treating theological and metaphysical ideas as having played essential functions in the past, and as being the ground out of which science emerges. Most important of all, he insisted that science must perform the same social functions as religious thinking, not least in securing social solidarity. ${ }^{4}$ There are parallels between this aspect of his position

Kolakowski (1972) has a chapter headed 'Positivism down to David Hume', in which he refers to 'medieval positivism', referring for instance to the ideas of Roger Bacon and William of Ockham, as well as recognizing the anti-metaphysical arguments of the ancient sceptics. I have drawn heavily on Kolakowski's excellent book.

4 In fact, he often portrays the 'metaphysical' state or stage as a transitional one in which social order was not secured, as illustrated by the French Revolution (see Gane, 2006). 
and the philosophies of Hegel and Marx, and it represents a sharp difference from many later positivists.

Nevertheless, central to positivism for Comte, as well as to $19^{\text {th }}$-century statistical investigations of society (from which he nevertheless sought to distance himself), was the idea that science could provide a sound basis for action, in particular for reconstructing society in a modern form. Comte argued that society should now be organized so as to comply with an understanding of the facts of human nature, societal development, and current social conditions, as documented by sociological analysis - rather than being based upon speculative ideas, not just theological ones but also 'metaphysical' notions like human rights, equality, and democracy. This reflected his conception of science as concerned solely with what can be empirically documented.

Comte's conception of science drew on the work of Bacon and Newton as well as on his knowledge of subsequent scientific investigation across a range of fields. His position was anti-metaphysical in the sense that he rejected claims to knowledge of first and final causes, or about the essence of types of phenomena, which had been characteristic of much medieval science. He also rejected the concept of causation as metaphysical. Instead, he saw the task of science as empirical documentation and classification of observable features of phenomena, and careful inference based on this, with a view to discovering universal laws. At the same time, he did not see evidence as consisting of particularised senseimpressions, in the way that many British empiricists did, but adopted a broader conception which included general not just particular facts. Much the same orientation informed social statistical investigations, except that the generalisations they produced tended to be probabilistic rather than universal in character; and the statistical techniques employed were concerned with documenting variation rather than uniformity (MacKenzie, 1981).

Another distinctive feature of Comte's positivism was that - rather than believing that science is based on a single logic - he argued that the various sciences differ somewhat in their assumptions and methods, while at the same time forming part of an integrated structure. Moreover, he saw those assumptions and methods as having emerged through a process of discovery in the course of the historical development of each science (out of theological and metaphysical ideas). The more abstract, foundational sciences - notably astronomy, mathematics and physics - arise first, others only later, building on the knowledge and methods of these but also developing their own distinctive means of understanding the specific character of the phenomena they investigate. Furthermore, Comte initially saw the whole structure of the sciences as being completed by the emergence of social science, which he originally called 'social physics' but subsequently labelled 'sociology', in order to distinguish it from Quételet's social sta- 
tistical discipline that had been given the same name. Comte saw sociology as serving to coordinate the use of scientific knowledge of all kinds in the reconstruction of society. ${ }^{5}$

Comte's work had an impact on John Stuart Mill, who wrote what was probably the most influential book on scientific method in the $19^{\text {th }}$ century: A System of Logic, Ratiocinative and Inductive. While Mill never declared himself to be a positivist, he was in contact with Comte and shared some key assumptions with him, in particular an emphasis on science as exemplifying rationality, and an insistence that all knowledge is founded on empirical evidence, along with an opposition to metaphysics and all reliance upon a priori argument. While there are some significant differences in view between them, Mill's account of science has often been labelled positivist. ${ }^{6}$

In the early $20^{\text {th }}$ century a new version of positivism emerged, the logical positivism of the Vienna Circle, though it drew on the earlier work of the physicist Ernst Mach, the philosopher Richard Avenarius, the psychologist and statistician Karl Pearson, and the English philosopher Bertrand Russell. These later positivists shared some of Comte's and Mill's assumptions but rejected others, as well as differing amongst themselves in some key respects (see Kolakowski, 1972). The primary concern of the logical positivists was to develop a rigorous conception of science, in light of the radical implications of Einstein's theory of relativity - earlier conceptions of science had tended to assume the validity of Newtonian ideas. As this implies, unlike Comte they treated physics as the most advanced science,

Just as Saint-Simon's followers constituted a movement committed to bringing about the sort of society envisaged by their leader, so Comte (who had been Saint-Simon's secretary) saw his philosophy as providing the charter for a movement that could facilitate the emergence of the new form of society. Indeed, he proposed the positive philosophy as a civil religion, and positivist churches were established, not just in France but also in England and in several Latin American countries, while the influence of positivism was even wider, spreading to other parts of Europe, including Poland, and to the United States (Hawkins, 1936, 1938; Charlton, 1959; Simon, 1963; Miłosz, 1983, ch. 8; Wright, 1986).

6 As already mentioned, one of the most important differences, as regards the theory of science, was that Comte insisted that there were general as well as particular facts, these necessarily being identified within the systematic conceptual scheme defining the relevant science, rather than simply being given to consciousness. By contrast, Mill believed that we could only have experience of particulars. Relatedly, Comte rejected psychology as the basis for science, whereas Mill took it to be crucial. A further area of disagreement concerned Comte's treatment of the concept of cause as metaphysical: Mill argued that this makes it impossible to distinguish between mere succession of instances of particular types of event, and one type of event generating another; in other words, it seems to imply that all correlations are laws: see Lewisohn, 1972. Scharff (1995) has argued that these two thinkers held fundamentally different conceptions of science, and claims that whereas Mill shares much in common with $20^{\text {th }}$ century logical positivists, Comte's positivism has much more relevance for post-positivism, that it has a contemporary philosophical relevance that Mill's work lacks. 
and as a model for all others. Nevertheless, like earlier positivists, they insisted that science is demarcated from metaphysics through its rigorous reliance solely upon logical inference from empirical evidence. However, they drew on advances in the understanding of logic made at the end of the nineteenth and beginning of the twentieth centuries, by Frege, Russell and others, which included the idea that the foundations of mathematics lie in logic. This prompted a linguistic turn in philosophy, which insisted that the focus should be on the syntax and semantics of statements and their components, rather than (as previously) on the analysis of psychological judgments. The aim was to clarify what could be meaningfully related to empirical givens, and what forms of inference are legitimate from these. In particular, logical analysis provided a means of identifying spurious forms of inference and thereby facilitated the rejection of metaphysics. What was most distinctive about logical positivism was that it ruled out as literally meaningless any statement that was not either analytic or empirically testable.

Another important component of logical positivism was commitment to the unity of science, this being premised not just on a common conception of scientific method but also on a formal language, drawing on logic, in terms of which scientific theories in all fields could be formulated. Indeed, these positivists sometimes went beyond this in claiming that the findings of all of the sciences would eventually be derivable from the tenets of Physics. Here, there was a sharp contrast with Comte, who rejected reductionism; and also with Mill who, like Comte, denied that the inductive methods employed by natural scientists were applicable in social science, recommending instead what he called the inverse deductive method' (Lewisohn, 1972, pp. 323-324). For logical positivists, what was central to science was the measurement and manipulation of variables, designed to discover universal laws. ${ }^{7}$ And this encouraged the development of various kinds of quantitative social science in the first half of the $20^{\text {th }}$ century, these building on the older social statistics tradition.

\section{Positivism and social science}

As we saw, the development of social science was envisaged by Comte as the crowning achievement in the development of scientific knowledge, and as essential if this knowledge was to be employed in the reconstruction of society. Later philosophical positivists frequently had less interest in, and sometimes a negative view of, social science. Nevertheless, in the nineteenth and early $20^{\text {th }}$ centuries social science was widely promoted as providing an essential foundation for 
sound policymaking, and as involving the application of what could be learned about scientific inquiry from the natural sciences. In Britain, for example, this trend drew on the work of Comte and Mill, and often involved sharp rejection of earlier forms of social thought. Central here was an insistence on the importance of empirical facts; that knowledge is only possible regarding factual matters - not theological, metaphysical, or even ethical ones; and that gaining such knowledge requires the systematic collection and analysis of evidence.

Some social scientists employed experimental method, albeit modified for the study of human beings, for example in social psychology and among sociologists studying small groups. But, even where experimental investigation was deemed impossible, the experiment was taken as an ideal that had to be approximated, for instance by survey researchers. In the US during the 1920s and 30 s, some sociologists were directly influenced by logical positivism and related trends, such as operationism (see Hammersley, 1989, ch. 4). In the study of politics, there was rejection of the tradition of political philosophy, which was normative in character, in favour of investigating how political systems actually function, and there was an increasing preoccupation with what could be counted and measured, such as voting patterns.

However, both across the social sciences and within particular ones, there was considerable variation in what was rejected, as well as in views about how social science ought to be pursued. This partly reflected the influence of different versions of positivism, but was also shaped by the practical business of trying to do social science. Indeed, Lazarsfeld (1962) complained that positivist philosophers of science had failed to take account of the progress that social science had made, or to offer guidance about the distinctive practical problems that it faced. And some of the divergences to be found in positivist-influenced research in social science reflected variation in the topics and phenomena investigated: studies of decision-making in small groups involved different problems from those concerned with explaining voting patterns across Western nations, for instance.

Neither experimental nor survey research became the only kind of work carried out in social science, but they were dominant in some disciplines for much of the $20^{\text {th }}$ century, and they remain influential today - furthermore, the use of experimental method has recently been boosted as a result of the evidence-based practice movement (Hammersley, 2013). It is also worth noting that, in the 1950s and early 60s, the influence of positivism extended even to those methods largely rejected by positivists, such as participant observation, these often being conceptualised in ways that were shaped by positivist ideals (see, for instance, Becker, 1958; McCall, Simmons, 1969).

Of course, those ideals were never uncontested - within social science or, for that matter, within philosophy - and from the middle of the $20^{\text {th }}$ century on- 
wards they came under increasing challenge in both areas (see Halfpenny, 1982). In the wake of this, various kinds of post-positivism began to be influential within social science. These drew on other sets of philosophical ideas than positivism, including pragmatism, Popper's critical rationalism, phenomenology, critical realism, hermeneutics, structuralism, and post-structuralism.

\section{Post-positivism in social science}

In social science, from the middle of the $20^{\text {th }}$ century, the dominance of quantitative method, and the positivist ideas associated with it, were increasingly questioned (though in some countries, and some fields, more than others), and there was a flowering of qualitative inquiry across several disciplines and applied areas. This took a variety of forms, some inspired by ethnographic work in anthropology, some by case study and community study in sociology, some by clinical interviewing in psychology. As I have noted, initially qualitative researchers adopted a defensive stance, seeking to justify their work in broadly positivist terms, and certainly to defend its scientific character. However, over time, qualitative researchers came increasingly to reject positivism, and indeed many came to question whether a social science was possible or desirable.

I will distinguish between two kinds of post-positivism. Sometimes this label is restricted to those approaches within social science that have retained central elements of a positivist approach - for instance, the idea that natural science is a key model for all knowledge production - while revising others in light of the philosophical criticism of positivism within the analytic tradition of philosophy that arose in the middle of the $20^{\text {th }}$ century, for example in the work of Quine, Davidson and Putnam, as well as Popper's falsificationism. Pragmatism (in the strands deriving from Peirce and Dewey) was also sometimes drawn on, as a more catholic tradition than positivism, but one that still treated science as central to modern life, insisting on its practical character and function (see, for instance, Phillips, Burbules, 2000). This revisionist form of post-positivism supported the continuation of experimental and survey research, as well as some kinds of qualitative work, such as the sort of case study championed in recent Anglo-American political science (see Goertz, Mahoney, 2012).

The second, more radical, interpretation of 'post-positivism' constitutes a much more diverse field, reflecting, in part, the wide variety of philosophical ideas employed and the conflicts amongst them. These included $19^{\text {th }}$ - and $20^{\text {th }}$ century forms of hermeneutics, Marxism, phenomenology, ethnomethodology, structuralism, post-structuralism, postmodernism, and most recently 'new materialism' and posthumanism (influenced by the work of Deleuze, Latour, Barad, 
and others). These approaches pose a much more fundamental challenge to positivism, and the previously dominant approaches to social science that drew on it. Not only is the positivist conception of science rejected, but so too is the idea that natural science is an appropriate model for social inquiry, for example on the grounds that it amounts to colonisation of the lifeworld by a technicist orientation that is not just epistemologically and ontologically illegitimate but also ethically and politically undesirable.

A central component of many of these philosophical ideas was what has been referred to as constructionism, which questioned the realist assumptions that had previously underpinned both quantitative and much qualitative research: the idea that there are social phenomena existing independently of the research process which it is possible to represent accurately. First of all it was argued that social phenomena must be viewed as the products of people exercising agency rather than as the outcome of causal forces that could be studied in the same manner that a physicist studies physical objects. Moreover, this conception of people actively making sense of their environment and acting on the basis of the cultural understandings they develop came to be extended to the social scientist her or himself. It was argued, therefore, that research necessarily constitutes the world it investigates through the concepts it uses and the methods of inquiry adopted. This implied that researchers employing different cultural assumptions would produce different accounts, and that these would have to be treated as valid in their own terms. It was insisted that there could be no cultural neutrality, no 'view from nowhere', no documentation of reality as it is 'in itself'. With the development of constructionism the meaning of 'positivism' came to be conflated with that of 'realism'.

Generally speaking, this second kind of post-positivism has promoted the value of qualitative data and qualitative forms of analysis; and, in its more radical forms, these are reinterpreted in terms derived from art and literature, including the production of fictions or poems and/or the promotion of various kinds of performance art (Leavy, 2015). Indeed, some have announced a 'post-qualitative' phase (Lather, St. Pierre, 2013). Equally important have been arguments about the political function of social science, with positivism treated as supporting the status quo, whereas the point (it is assumed by the critics) is to challenge it (as, for instance, with the Perestroika movement in political science - see Monroe, 2005). As part of this, there has been explicit commitment to one or another broadly Leftist orientation, whether this is anti-capitalism, feminism, anti-racism, queer politics, or disability activism. There have also been ethical as well as political arguments to the effect that qualitative research must give voice to participants, particularly those whose voices are suppressed within current society. ${ }^{8}$

For an interesting assessment of these forms of critical social science from within, see Sayer, 2009. 
All of these developments derive from rejection of any claim by social scientists to be able to produce objective knowledge, commitment to this often being taken as the central component of positivism.

\section{Discussion}

I have traced, in outline, an intellectual trend from a time when positivism exerted a strong influence over social science in the late nineteenth and early $20^{\text {th }}$ centuries to the situation today when, while its influence continues in some quarters, in others it has been fundamentally rejected by radical forms of postpositivism. As a result, there is now a huge variety of forms of 'post-positivist' research. It is widely assumed that this decline in the influence of positivism represents progress; though sometimes any notion of progress is itself dismissed as positivist. Indeed, the sheer diversity of approaches now prevailing in social science is regarded as desirable by some, as against what is regarded as the 'closed' orientation of positivism (see Hodkinson, 2004; Hammersley, 2005).

It is certainly true that positivism had failings, in both its philosophical and social science forms. Interestingly, many of these were recognised and discussed early on by positivists themselves, and by others who shared much the same outlook: this did not wait for post-positivism (see Kolakowski, 1968). Some of these problems were irresolvable without significant modification of the initial assumptions of positivists, along the lines of the first, revisionist, kind of postpositivism I mentioned. An example would be the problem of how to distinguish between mere correlations and causal relations. In this connection, Halfpenny (1982, pp. 77-86) has outlined the problems surrounding efforts to apply the notion of causal modelling in sociology, and social science more generally. To a large extent, these problems remain despite subsequent developments in technique (see Abbott, 1998). Another feature of positivism that has generally been rejected is the tendency towards radical forms of reductionism or behaviourism, on the grounds that this loses sight of the distinctive character of social phenomena (Halfpenny, 1982, p. 91).

As this indicates, there are some respects in which it is still necessary to resist the influence of positivism. However, I suggest that, against the background of the diverse forms of radical post-positivist research now practised, and their anti-realist character, we ought to re-examine positivism. Much qualitative research in social science today pays insufficient attention to the fact that some of the claims it makes are quantitative in form, and may require the precision of counting or measurement if they are to be established. Even more importantly, there is a widespread failure to recognise the stringent requirements that must 
be met if the validity of the conclusions reached is to be well-established. ${ }^{9}$ Also lacking, frequently, is clarity about whether the goal of producing explanatory knowledge has been retained or abandoned; indeed, about whether the enterprise involved is still scientific inquiry, or indeed any sort of inquiry (rather than political activism or storytelling).

What can be learned from positivism, I suggest, is a commitment to the importance, and feasibility, of pursuing scientific knowledge of social phenomena; accompanied by recognition of the limits to that knowledge, and of the importance of distinguishing reliable from more speculative knowledge claims (this being a dimension not a dichotomy); an emphasis on the need for clarity about key concepts, to the degree that this is possible and necessary; and a stress on the importance of testing knowledge claims, along with the evidence put forward in support of them. It is not that these commitments have disappeared, but they have been greatly weakened in practice as well as being explicitly rejected by influential radical commentators (see Hammersley, 2008). The great virtue of positivism is a cautious commitment to clarifying and seeking to resolve intellectual problems rather than treating these as fundamental and completely intractable, so that adopting one view rather than another requires a leap of faith.

In pursuing a re-evaluation of positivism, it is worth noting two fairly recent developments in scholarship relating to it. The first is a resurgence of interest in the work of Comte. Previously, early Comte had been portrayed as developing the outlines of a positivist approach, concerned with the production of objective knowledge, whereas his later work had been dismissed as veering towards a more subjective approach, culminating in his promotion of the positivist religion. In other words, as Bourdeau (2018) remarks, a distinction was drawn between a 'good Comte' and a 'bad Comte. However, more recent scholars have emphasised the continuities in his work, and argued that the view of him as a positivist, in the sense of the term used later to refer to Mill and logical positivists, is misleading. Indeed, it has been suggested that, in important respects, he was post-positivist avant la lettre (see Scharff, 1995; Gane, 2006; Schmaus, 2008; Bourdeau et al., 2018). Furthermore, there are parallels between this re-reading of Comte and some forms of post-positivism in qualitative research today. For example, Gane argues that Comte's philosophical system was designed as a fiction to capture the future, with a view to evaluating the present. And he draws comparisons between Comte's orientation and 'postmodern' writers, such as Baudrillard (see Gane, 2006, pp. 20-21).

For one argument along these lines, see Lubet, 2018. 
I regard this recent Comte scholarship as providing an important counter to earlier stereotypical accounts of his work, and as underlining his distinctive attitudes on key issues. It is certainly the case that he had a more sophisticated understanding of methodological differences across the sciences compared with later positivists, and did not succumb to their preoccupation with physics as a model for scientific method. In this respect his descendants are Bachelard and Canguilhem and their historical epistemology (Lecourt, 1975). However, in my view this recent scholarship has also given value to aspects of his work that are positively damaging for social science, such as the idea that it could serve as a civil religion or as a form of art.

The second development I want to mention has been increased historical and philosophical attention to the ideas of the logical positivists. This has involved showing that there were significant differences in view amongst members of the Vienna Circle, and within the wider positivist movement during the first half of the $20^{\text {th }}$ century. Equally important has been pointing out that their thinking was not completely cut off from trends in continental philosophy. It is also argued that standard accounts of their positions verge on caricature: that, contrary to what those accounts imply, they recognised the role of non-empirical axioms in knowledge production and the assumption-ladenness of observation (see Cartwright et al., 1996; Friedman, 1999, 2000; Richardson, Uebel, 2008). In these respects, they too were post-positivist, though in the first (revisionist) sense of that term rather than the second (radical) one.

\section{Conclusion}

While for Comte, and others, social science was to play a central role in providing practical guidance within modern societies, in effect its influence has been more mediated and contingent. Of much greater significance has been the development of organisational systems for counting and measurement designed to document performance and outcomes of various kinds, whether relating to individuals, organisations, or whole national economies (see Porter, 1996). Similarly, while the early positivists anticipated a rapid growth in the production of knowledge about the social world, taking the form of universal scientific laws, social science has failed to achieve this goal. It is this failure, above all, that has led to its diversification and fragmentation today. It seems to me that we are at an impasse. And, in trying to find our way forward we should draw on all the resources available to us, rather than dismissing some out of hand. In other words, there could even be something to be learned from that old bugbear positivism. 


\section{References}

Abbott, A. (1998). “The Causal Devolution”. Sociological Methods and Research, 27(2), pp. $148-181$.

Abrams, P. (1972). The Origins of British Sociology 1834-1914. Chicago: University of Chicago Press.

Baker, K.M. (1975). Condorcet: From Natural Philosophy to Social Mathematics. Chicago: University of Chicago Press.

Becker, H.S. (1958). "Problems of Inference and Proof in Participant Observation". American Sociological Review, 23, pp. 652-660.

Bourdeau, M. (2018). “Auguste Comte”. The Stanford Encyclopedia of Philosophy (Summer 2018 Edition), Edward N. Zalta (ed.). URL $=<$ https://plato.stanford.edu/archives/sum2018/entries/comte/>.

Bourdeau, M., Pickering, M., Schmaus, W. (eds.) (2018). Love, Order, and Progress: The Science, Philosophy, and Politics of Auguste Comte. Pittsburgh, PA: University of Pittsburgh Press.

Bryant, C.G.A. (1985). Positivism in Social Theory and Research. London: Macmillan.

Cartwright, N., Cat, J., Fleck, L., Uebel, T. (1996). Otto Neurath: Philosophy between Science and Politics. Cambridge: Cambridge University Press.

Charlton, D.G. (1959). Positivist Thought in France during the Second Empire, 1852-1870. Oxford: Oxford University Press.

Cohen, P. (1980). “Is Positivism Dead?”. Sociological Review, 28(1), pp. 141-176.

Friedman, M. (1999). Reconsidering Logical Positivism. Cambridge: Cambridge University Press.

Friedman, M. (2000). A Parting of the Ways: Carnap, Cassirer, and Heidegger. Chicago: Open Court.

Gane, M. (2006). Auguste Comte. London: Routledge.

Goertz, G., Mahoney, J. (2012). A Tale of Two Cultures: Qualitative and Quantitative Research in the Social Sciences. Princeton, NJ: Princeton University Press.

Halfpenny, P. (1982). Positivism and Sociology. London: Allen \& Unwin. (Republished by Routledge, 2015).

Hammersley, M. (1989). The Dilemma of Qualitative Method: Herbert Blumer and the Chicago Tradition. London: Routledge.

Hammersley, M. (1995). The Politics of Social Research. London: Sage.

Hammersley, M. (2005). “Countering the 'New Orthodoxy' in Educational Research: A Response to Phil Hodkinson”. British Educational Research Journal, 31(2), pp. 139-155.

Hammersley, M. (2008). Questioning Qualitative Inquiry: Critical Essays. London: Sage. Hammersley, M. (2013). The Myth of Research-based Policy and Practice. London: Sage. Hawkins, R.L. (1936). Auguste Comte and the United States, 1816-1853. Cambridge, MA: Harvard University Press. 
Hawkins, R.L. (1938). Positivism in the United States (1853-1861). Cambridge, MA: Harvard University Press.

Hodkinson, P. (2004). "Research as a Form of Work: Expertise, Community and Methodological Objectivity”. British Educational Research Journal, 30(1), pp. 9-26.

Kolakowski, L. (1972). Positivist Philosophy. Harmondsworth: Penguin.

Lather, P., St. Pierre, E. (2013). “Post-qualitative Research”. International Journal of Qualitative Studies in Education, 26(6), pp. 629-633.

Lazarsfeld, P. (1962). "Philosophy of Science and Empirical Social Research". In: E. Nagel, P. Suppes, A. Tarski (eds.). Logic, Methodology and Philosophy of Science. Stanford, CA: Stanford University Press.

Leavy, P. (2015). Method Meets Art: Arts-based Research Practice. $2^{\text {nd }}$ edition. New York: The Guilford Press.

Lecourt, D. (1975). Marxism and Epistemology. London: New Left Books.

Lenzer, G. (ed.) (1975). Auguste Comte and Positivism: The Essential Writings. New York: Harper \& Row.

Lewisohn, D. (1972). "Mill and Comte on the Methods of Social Science". Journal of the History of Ideas, 33(2), pp. 315-324.

Lubet, S. (2018). Interrogating Ethnography: Why Evidence Matters. Oxford: Oxford University Press.

MacKenzie, D. (1981). Statistics in Britain 1865-1930. Edinburgh: Edinburgh University Press.

McCall, G., Simmons, J. (eds.) (1969). Issues in Participant Observation. Reading, MS: Addison-Wesley.

Manuel, F. (1956). The New World of Saint-Simon. Cambridge, MA: Harvard University Press.

Mill, J.S. (1865/1961). Auguste Comte and Positivism. Ann Arbor, MI: University of Michigan Press.

Miłosz, Cz. (1983). The History of Polish Literature. Berkeley, CA: University of California Press.

Monroe, K.R. (ed.) (2005). Perestroika! The Raucous Rebellion in Political Science. New Haven, CT: Yale University Press.

Oberschall, A. (1972). The Establishment of Empirical Sociology. New York: Harper \& Row.

Phillips, D., Burbules, N. (2000). Postpositivism and Educational Research. Lanham, MD: Rowman \& Littlefield.

Pickering, M. (1993a). Auguste Comte: An Intellectual Biography, Vol. 1. Cambridge: Cambridge University Press.

Pickering, M. (1993b). "Auguste Comte and the Saint-Simonians". French Historical Studies, 18(1), pp. 211-236.

Porter, T. (1986). The Rise of Statistical Thinking. Princeton, NJ: Princeton University Press. 
Porter, T. (1996). Trust in Numbers: The Pursuit of Objectivity in Science and Public Life. Princeton, NJ: Princeton University Press.

Richardson, A., Uebel, T. (eds.) (2008). The Cambridge Companion to Logical Empiricism. Cambridge: Cambridge University Press.

Sayer, A. (2009). "Who's Afraid of Critical Social Science?”. Current Sociology, 57(6), pp. 767-786.

Scharff, R.C. (1995). Comte after Positivism. Cambridge: Cambridge University Press.

Schmaus, W. (2008). "Rescuing Auguste Comte from the Philosophy of History: Review of Les Trois États: Science, théologie et métaphysique chez Auguste Comte by Michel Bourdeau". History and Theory, 47(2), pp. 291-301.

Simon, W. (1963). European Positivism in the Nineteenth Century. Port Washington, NY: Kennikat Press.

Staum, M. (1996). Minerva's Message: Stabilizing the French Revolution. Kingston: McGill-Queen's University Press.

Taylor, C. (1964). The Explanation of Behaviour. London: Routledge \& Kegan Paul.

Wernick, A. (2001). Auguste Comte and the Religion of Humanity: The Post-theistic Program of French Social Theory. Cambridge: Cambridge University Press.

Wright, T.R. (1986). The Religion of Humanity: The Impact of Comtean Positivism on Victorian Britain. Cambridge: Cambridge University Press. 